Електронне наукове фахове видання "Ефективна економіка" включено до переліку наукових фахових видань України з питань економіки

(Категорія «Б», Наказ Міністерства освіти і науки України від 11.07.2019 № 975) www.economy.nayka.com.ua | № 2, 2022|24.02.2022 p.

DOI: $10.32702 / 2307-2105-2022.2 .12$

УДК 657

T. С. Кучеренко,

д. е. н., професор, професор кафедри обліку і оподаткування,

Уманський національний університет садівництва, Умань, Украӥна

ORCID ID: 0000-0001-7056-4344

Г. Ю. Анішенко,

к. е. н., дочент, доиент кафедри обліку і оподаткування,

Уманський національний університет садівництва, Умань, Україна

ORCID ID: 0000-0001-9603-6662

\title{
ОБЛІКОВО-АНАЛІТИЧНЕ ЗАБЕЗПЕЧЕННЯ УПРАВЛІННЯ ГРОШОВИМИ ПОТОКАМИ ПІДПРИЕМСТВ
}

\author{
T. Kucherenko \\ Doctor of Economic Sciences, Professor, Professor of the Department of Accounting and Taxation, \\ Uman National University of Horticulture, Uman, Ukraine \\ H. Anishchenko
}

PhD in Economics, Associate Professor, Associate Professor of the Department of Accounting and Taxation, Uman National University of Horticulture, Uman, Ukraine

\section{ACCOUNTING AND ANALYTICAL SUPPORT OF CASH FLOW MANAGEMENT OF ENTERPRISES}

У статті досліджено необхідність удосконалення на вітчизняних підприємствах відповідної роботи з обліково-аналітичного забезпечення управління грошовими потоками, адже їх всебічна оцінка є невід'ємною складовою управлінської роботи. Висвітлено особливості обліково-аналітичного забезпечення грошових потоків та напрацьовано конкретні иляхи удосконалення обліково-звітного процесу з наступним включенням отриманих даних до інформаційної системи фінансової очінки та управління бізнесом. Виокремлено та проаналізовано роль $і$ місие обліково-аналітичного забезпечення серед етапів управління грошовими потоками, иляхом структурування прочесів формування управлінської інформації про рух грошових коштів та виділення його окремих стадій. Чітко визначено, що дотримання алгоритму управління грошовими потоками безпосередньо залежать від обліково-звітної системи, яка складає інформаційну основу для генерування управлінських рішень. Обгрунтовано доцільність започаткування на підприємствах практики складання бюджетів грошових потоків, щуо дозволить контролювати платоспроможність суб'єкта на кожну звітну дату, визначати напрями та дочільність використання як власних, так $i$ залучених грошових коштів, своєчасно виявляти негативні тендениії з грочовими операціями. Визначено, щзо завдяки застосуванню бюджетування та фінансового контролінгу за грошовими потоками досягається удосконалення обліковоаналітичного забезпечення управління ними. Доведено, що иьому процесу сприятимуть заходи з повної автоматизачіі бухгалтерського обліку, застосування програмного забезпечення та відповідних інформаційних технологій обробки економічних даних за регульованими параметрами під запити управлінського персоналу. Запропонований перелік оціночних показників для аналізу грошових потоків підприємства сприяє кращому розумінню 
його фінансового стану. Розкрито підходи до проведення даного аналізу із застосуванням варіантів розрахунків як за розширеним, так $і$ експрес-аналізом, які дають можливість повною мірою оцінити грошові потоки підприємства. Узагальнено фактори, завдяки яким відбувається поліпшення обліково-аналітичного забезпечення прочесу управління грошовими потоками та які впливають на загальне виконання завдань стратегічного управління.

The article examines the need to improve the relevant work in domestic enterprises on accounting and analytical support of cash flow management, as their comprehensive assessment is an integral part of management work. The peculiarities of accounting and analytical support of cash flows are highlighted and specific ways to improve the accounting and reporting process with the subsequent inclusion of the obtained data in the information system of financial evaluation and business management. The role and place of accounting and analytical support among the stages of cash flow management, by structuring the processes of formation of management information about cash flows and the allocation of its individual stages were identified and analyzed. It is clearly defined that compliance with the cash flow management algorithm directly depends on the accounting system, which is the information basis for generating management decisions. The expediency of initiating the practice of cash flow budgeting at enterprises was substantiated, which will control the solvency of the entity at each reporting date, determine the direction and feasibility of using both own and borrowed funds, timely identify negative trends in the cash transactions. It is determined that due to the use of budgeting and financial controlling of cash flows, the improvement of accounting and analytical support of their management is achieved. It is proved that this process will be facilitated by measures for full automation of accounting, application of software and relevant information technologies for processing economic data on adjustable parameters at the request of management staff. The proposed list of evaluation indicators for the analysis of cash flows of the enterprise contributes to better understanding of its financial condition. Approaches to conducting this analysis with the use of calculation options for both advanced and express analysis, which allow to fully assess the cash flows of the enterprise, were revealed. The factors, due to which the improvement of the accounting and analytical process of cash flow management, which effect on the overall implementation strategic management tasks, were generalized.

Ключові слова: грошові потоки; грошові кошти; Звіт про рух грошових коштів; оцінка грошових потоків; обліково-звітна система; обліково-аналітичне забезпечення; управління.

Keywords: cash flows; cash; statement of cash flows; assessment of cash flows; accounting system; accounting and analytical support; management.

Постановка проблеми. Грошові потоки є важливим елементом ефективної діяльності підприємства, тому обліково-аналітичне управління ними забезпечує практичні потреби управлінського менеджменту щодо аналізу фінансового стану, ліквідності, платоспроможності. У практиці фінансового обліку практично відсутній цілісний і взаємопов'язаний облік грошових потоків. Це пояснюється відсутністю такого об'єкта обліку та звітності як «грошові потоки», а наявністю лише «грошових коштів». Грошові потоки узагальнюють процес кругообігу активів підприємства, характеризують джерела формування усього капіталу та фактори забезпечення його обороту. Через це оцінка грошових потоків підприємства повинна бути провідним етапом визначення ефективності управління фінансами для будь-якого підприємства, визначення його фінансового стану, що вимагає від обліково-аналітичної системи підприємств надійних та достовірних даних, згенерованих у результаті надходження та витрачання грошових коштів та їх еквівалентів. Разом $з$ тим формування загальної інформації про грошові потоки відбувається на основі однієї з обов'язкових форм фінансової звітності - Звіті про рух грошових коштів. Власне їх рух і формує зазначені потоки та дозволяє у загальному зрозуміти надходження та витрачання грошових коштів за звітний період у розрізі видів діяльності. Проте спеціалізована інформація про грошові потоки, яка була б придатна для системи менеджменту більше відноситься до внутрішньогосподарської звітності. Через те, що керівництво підприємств більше переймається питаннями майнового забезпечення, дотриманням платіжної, особливо податкової, дисципліни, фінансовими результатами, тобто зосередження відбувається на «номінальній» звітній інформації, тим менше важливих даних залишається поза увагою щодо аналізу грошових потоків та ефективного управління ними. Разом 3 цим всебічна оцінка грошових потоків є невід'ємною складового бізнес-планування.

Аналіз останніх досліджень і публікацій. Теоретичні, організаційні та методичні аспекти сутності та формування інформації про грошові потоки підприємства, їх облік, аналіз досліджували багато вчених, таких як Аніщенко Г.Ю., Білецька К.М., Кошельок Г., Грінченко Р., Кундря-Висоцька О.П., Кучеренко Т.С., Мельник Л.Ю., Мова В.В., Семенова С.М. Ромашко О.М. та інші. Однак важливі питання методології обліку і аналізу 
грошових потоків, їх основної складової - грошових коштів, залежність фінансового стану підприємств від стабільності, розмірів і руху грошових потоків суб'єктів підприємництва залишаються відкритими. Достатність грошових коштів безпосередньо впливає на фінансовий стан, особливо за умов нестабільної чи швидкозмінної ринкової ситуації. Система управління грошовими потоками грунтується на здійсненні такої координації постачальницько-збутової діяльності підприємства, за якої функціонування виробничих етапів буде безперебійним. Безпосередньо управління грошовими потоками i грошовими коштами підприємств здійснюється переважно їх власниками, які не в повній мірі володіють проблемами ліквідності, платоспроможності фінансової стійкості підприємства, не враховують поточну ситуацію розрахунків 3 контрагентами з урахуванням відповідного обліково-аналітичного стану. Така робота здебільшого залишається поза увагою менеджерів підприємства. Основними чинниками низького рівня обліково-аналітичного забезпечення управління грошовими потоками $\epsilon$ відсутність постійного моніторингу грошових потоків у міжзвітний період, брак досвіду та нестача фахівців відповідної кваліфікації, низький рівень інформаційного забезпечення управлінського персоналу через відсутність добре налагодженого внутрішньогосподарського обліково-звітного процесу. Отже, існує необхідність у визначені проблем обліку, аналізу грошових потоків як основного чинника фінансового стану підприємства та удосконалення цих результатів в обліку і звітності.

Постановка завдання. Метою статті є дослідження особливостей обліково-аналітичного забезпечення грошових потоків та напрацювання конкретних шляхів удосконалення обліково-звітного процесу 3 наступним включенням отриманих даних до інформаційної системи фінансової оцінки та управління бізнесом.

Виклад основного матеріалу. Міжнародним законодавством визначено поняття грошових потоків як надходження та вибуття грошових коштів та їх еквівалентів. До грошових коштів відносять готівку в касі та депозити до запитання, а еквівалентами грошових коштів $є$ короткострокові високоліквідні інвестиції, що вільно конвертуються в відомі суми грошових коштів і яким властивий незначний ризик зміни вартості [9].

Рух грошових потоків, який представлено у фінансовій звітності Звітом про рух грошових коштів, інтерпретує, деталізує та відображає грошові потоки, що сформувалися внаслідок окремих видів діяльності: операційної, інвестиційної, фінансової. Водночас, Звіт про рух грошових коштів доповнює в певній мірі Звіт про фінансові результати (Звіт про сукупні доходи). Фінансовий результат підприємства залежить від цілого ряду подій і способів, які в тій чи іншій мірі впливають на його величину: метод оцінки запасів при вибутті, метод нарахування амортизації необоротних активів, створення резерву сумнівних боргів, визнання і оцінка біологічних активів і сільськогосподарської продукції (для сільськогосподарських підприємств) тощо. Таким чином, величина фінансового результату залежить від прийнятого суб'єктом господарювання в обліковій політиці методу оцінки окремих видів активів та їх класифікації.

Грошові потоки, у свою чергу, пов'язані із здатністю суб'єкта господарювання акумулювати грошові кошти в процесі досягнення заявлених поточних і стратегічних цілей. Надходження та вибуття грошових коштів певною мірою надає додаткову інформацію про здатність суб'єкта господарювання отримувати економічні вигоди від використання активів. «Економічна вигода - потенційна можливість отримання підприємством грошових коштів від використання активів» [11]. 3 метою виявлення тенденцій і закономірностей розвитку підприємства, швидкого реагування у ході управління підприємницькою діяльністю при негативному впливі факторів на фінансовий стан підприємства дуже важливо здійснювати моніторинг фінансового стану на постійній основі. Аналітичні розрахунки на основі фінансової звітності дозволять оцінити його платоспроможність і ліквідність, рівень фінансової стійкості й ділової активності, обсяги і якість дебіторської та кредиторської заборгованості. Управління грошовими потоками являє собою певну систему методів та принципів, розроблення управлінських рішень та їх реалізацію, пов'язаних з формуванням, розподілом і використанням грошових коштів та організацією їх обігу, спрямованих на забезпечення фінансової рівноваги корпорації та іiі стійкого зростання [10]. Система управління грошовими потоками $\epsilon$ складною та впорядкованою множиною засобів впливу на грошові кошти підприємств та напрями їх руху 3 метою упорядкування їх в єдиний цілісний процес для досягнення фінансової стійкості суб'єкта діяльності. Обліково-аналітична інтерпретація взаємозв'язку елементів даної системи управління наведено на рис. 1 та свідчить про тісну взаємодію підприємства із зовнішнім середовищем у процесі якої власне і відбуваються грошові операції. При цьому обліково-аналітичне забезпечення управління грошовими потоками $є$ процесом, який охоплює збір облікових даних (облікова реєстрація), зведення облікової інформації (звітність), аналіз отриманих масивів даних та підготовка варіантів управлінських рішень.

Грошові потоки генеруються за окремою групою операцій підприємства, які належать до грошових, тобто таких, які можуть відбуватися виключно за умови використання грошових коштів та їх еквівалентів. Такі операцій притаманні усім стадіям кругообігу капіталу. 3 метою управління ними необхідно дотримуватись чіткого алгоритму постановки й виконання завдань за етапами: планування та бюджетування грошових потоків, їх прогнозування; ідентифікація операцій, які належать до грошових потоків та збір, узагальнення й зведення облікових даних за ними; аналіз та інтерпретація даних про грошові потоки при підготовці проектів управлінських рішень; фінансовий контролінг та коригування й оптимізація параметрів грошових потоків. Усі наведені етапи управління грошовими потоками так чи інакше не можуть існувати без обліково-звітної системи, адже генерування управлінських рішень можливе виключно за умови отримання інформації про господарські операції, а це, у свою чергу, відбувається за рахунок належної організації та ведення бухгалтерського обліку. Серед елементів методу бухгалтерського обліку провідна роль належить документуванню та звітності, забезпечують фіксацію та репрезентативність операцій про рух грошових коштів. Організація обліково-аналітичної роботи через налагодження документообігу за грошовими операціями та 
ведення внутрішньогосподарського обліку й звітності дозволяють ефективність грошових потоків.

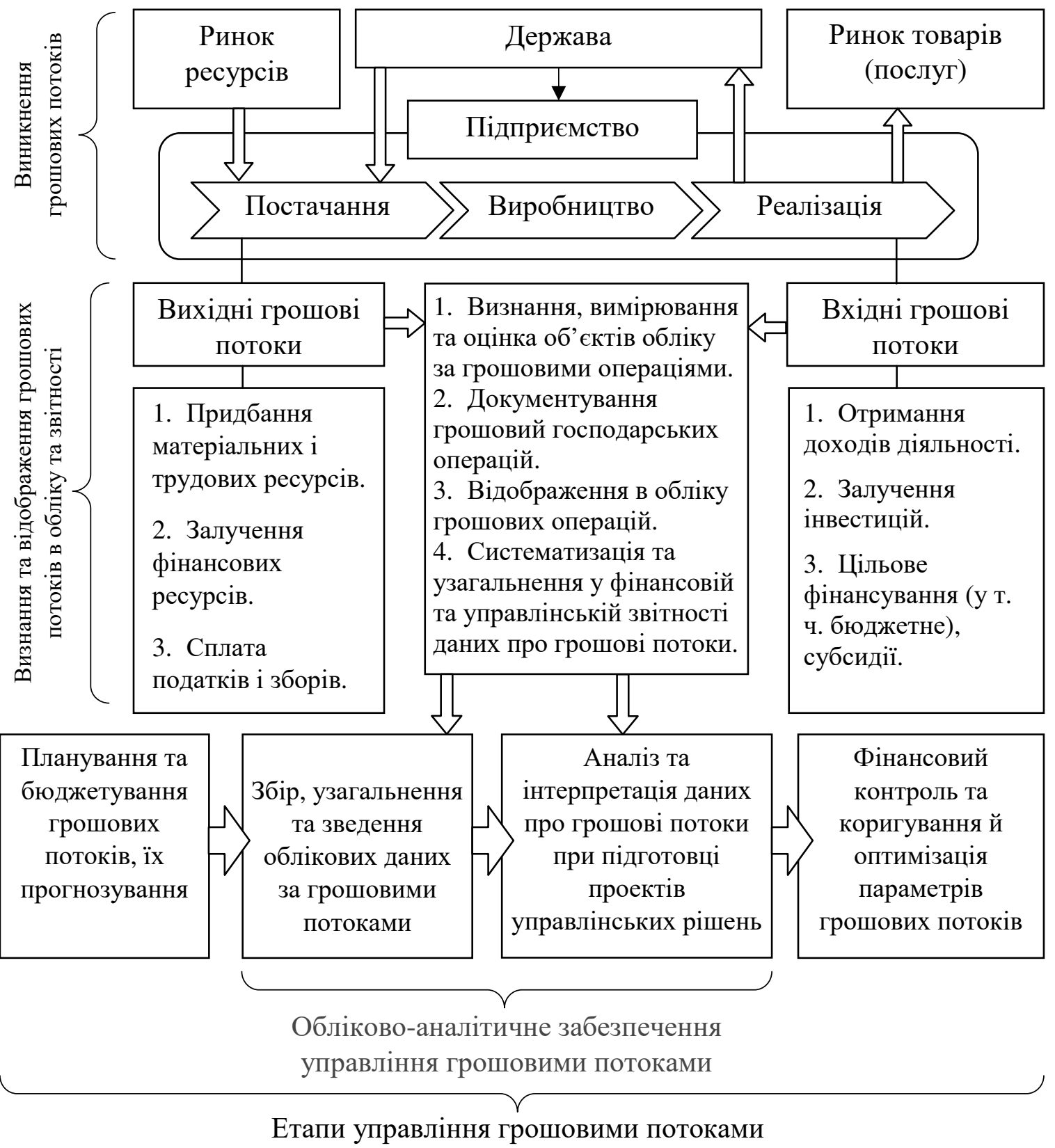
Рис. 1. Взаємозв’язок та обліково-економічний зміст елементів системи управління грошовими потоками
Джерело: складено авторами

Кундря-Висоцька О.П. стверджує: «Для побудови обліково-аналітичного забезпечення інтегрованого бухгалтерського обліку грошових потоків доцільно розробити систему показників інформаційного забезпечення управління на конкретному підприємстві, що дозволяє більш повно враховувати необхідну інформацію у процесі формування відповідного обліково-аналітичного забезпечення. У цих цілях обліковоаналітичне забезпечення може бути структуроване шляхом виділення фінансової і бухгалтерської інформації, даних управлінського обліку та фінансової звітності, а також даних, що формуються несистемним шляхом, із врахуванням зовнішніх факторів» [5]. Відповідне обліково-аналітичне забезпечення управління грошовими потоками базується на поєднанні фінансової та внутрішньогосподарської облікової системи, результатом взаємодії якої $є$ обліково-звітна інформація, як незамінний ресурс аналізу та обгрунтування адекватності обраний векторів розвитку. При цьому раціональне управління грошовими потоками дозволяє вирішити головне завдання підприємства - підвищення ефективності його функціонування та забезпечує фінансову рівновагу і безперебійність діяльності, прискорює капіталооборот, знижує ризик неплатоспроможності. Надходження і витрачання грошових потоків відбувається в результаті господарських операцій, що вимагає суворого їх цільового спрямування на досягнення поставлених господарських завдань. На наш погляд, для ефективного використання грошових коштів і аналізу руху грошових потоків суб'єкт господарювання має запровадити практику складання бюджетів грошових потоків, які узагальнюють інформацію обліку i фінансового аналізу грошових потоків за каналами і строками надходження і витрачання в розрізі видів 
діяльності. Бюджет надходжень і витрат грошових коштів дозволить здійснювати контроль за своєчасністю виконання операцій, а на основі проведеного фінансового аналізу платоспроможності, ліквідності - формувати інформацію про раціональність вкладення грошових коштів в операційну, інвестиційну чи фінансову діяльність. Це зокрема, дозволить контролювати платоспроможність суб'єкта на кожну звітну дату, визначати напрями використання як власних, так і залучених грошових коштів. Планування та контроль грошових потоків дозволить своєчасно виявляти негативні тенденції у грошових операціях, слідкувати за змінами у заборгованості та вживати відповідні заходи. Відсутність бюджетування на даній ділянці для керівництва підприємства означає, що доведеться лише констатувати результати руху грошових потоків за здійсненими господарськими фактами на кінець звітної дати, коли корективи вже нездійсненні, а будь-які заходи оперативного реагуванні неефективні. Саме через практичне застосування бюджетування та фінансового контролінгу за грошовими потоками досягається удосконалення обліково-аналітичного забезпечення управління грошовими потоками. Як складова загального фінансового контролінгу за діяльністю підприємства ця функція управлінської системи інформаційно-аналітичної взаємодії дозволяє забезпечити невід'ємну частину розробки та реалізації фінансової стратегії підприємства. Необхідність та доцільність цього продиктована потребою постійного моніторингу за ефективним управлінням грошових потоків.

Для запровадження повноцінного бюджетування грошових потоків необхідно вирішити декілька проблем з удосконалення обліково-аналітичної роботи на підприємствах. На нашу думку, по новому доцільно підійти до побудови інформаційної системи суб'єктів, які генерують грошові потоки, що полягає не лише у повній автоматизації бухгалтерського обліку, а й застосуванні програмного забезпечення та відповідних інформаційних технологій обробки економічних даних за принципами дашбордингу (створення, одержання, та аналіз даних в реальному часі). В умовах застосування інтернет-банкінгу для проведення грошових платежів стає можливою інтеграція облікових даних 3 інтерактивними аналітичними дашбордами 3 метою наочного подання інформації для користувачів-аналітиків, яка дозволяє швидко оцінити важливі показники та прийняти своєчасні рішення. Інформаційні панелі за грошовими потоками можуть мати різну інтерпретацію (таблиці, діаграми, карти), застосовуючи при цьому відхід від стандартного подання показників, що містяться у діючій формі Звіту про рух грошових коштів за прямим чи непрямим методом. Це можуть бути різноманітні структурні елементи надходжень та видатків за каналами позитивних та негативних грошових потоків, видами i сегментами формування, а також динаміка чистих результатів балансування грошових потоків та ряду розрахункових показників, визначених на їх основі. Через постійне збільшення обліково-аналітичної інформації зростаючою є потреба до застосування сучасних ресурсів та технологій їх обробки за регульованими параметрами під запити управлінського персоналу.

Застосування автоматизованої форми обробки облікової інформації компанії забезпечує не лише відображення облікових даних, але може змоделювати інформаційні потоки на поточний рік, розрахувати найбільш ефективні напрямки використання грошових коштів. Узагальнення інформації щодо обліку грошових потоків та оперативний фінансовий аналіз фінансового стану підприємства, його платоспроможності i ліквідності можна представити у створеному в автоматичному режимі регістрі обліку - Аналіз грошових потоків компанії «Альфа» (умовний приклад) (табл. 1).

Таблиця 1.

Аналіз грошових потоків компанії «Альфа»

\begin{tabular}{|l|c|c|c|}
\hline \multicolumn{1}{|c|}{ Показники } & $2019 \mathrm{p}$. & $2020 \mathrm{p}$. & $\begin{array}{c}\text { Бюджет на } \\
2021 \mathrm{p} .\end{array}$ \\
\hline $\begin{array}{l}\text { Чистий рух грошових коштів операційної діяльності, } \\
\text { тис. грн }\end{array}$ & 147626 & 153669 & 199800 \\
\hline $\begin{array}{l}\text { Чистий рух грошових коштів інвестиційної } \\
\text { діяльності, тис. грн }\end{array}$ & $(50157)$ & $(41142)$ & $(28800)$ \\
\hline $\begin{array}{l}\text { Чистий рух грошових коштів фінансової діяльності, } \\
\text { тис. грн }\end{array}$ & $(89509)$ & $(116304)$ & $(120000)$ \\
\hline Чистий рух грошових коштів, тис. грн & 7960 & $(3777)$ & 51000 \\
\hline Залишок грошових коштів, тис. грн & 8239 & 3345 & 9000 \\
\hline Дебіторська заборгованості, тис. грн & 52238 & 58502 & 60000 \\
\hline Оборотні активи, тис. грн & 242882 & 356079 & 522000 \\
\hline Власний капітал, тис. грн & 226597 & 360271 & 572800 \\
\hline Поточні зобов'язання, тис. грн & 171872 & 233242 & 200000 \\
\hline Довгострокові зобов'язання, тис. грн & 325997 & 280801 & 160000 \\
\hline Валюта балансу, тис. грн & 724466 & 874314 & 932800 \\
\hline Чистий оборотний капітал, тис. грн & 71010 & 122873 & 172000 \\
\hline Коефіцієнт абсолютної ліквідності & 0,05 & 0,01 & 0,04 \\
\hline Коефіцієнт швидкої ліквідності & 0,35 & 0,26 & 0,35 \\
\hline Коефіцієнт поточної ліквідності & 1,41 & 1,53 & 2,61 \\
\hline Коефіцієнт автономії & 0,31 & 0,41 & 0,61 \\
\hline Коефіцієнт фінансового левериджу & 2,30 & 1,44 & 0,63 \\
\hline Коефіцієнт концентрації позикового капіталу & 0,68 & 0,59 & 0,39 \\
\hline
\end{tabular}


Запропонований Аналіз грошових потоків призначено для більш глибокого розуміння динаміки i потенційної спроможності платоспроможності, фінансової стійкості підприємства, розроблення сценарію поліпшення руху грошових потоків, співвідношення їх використання між операційною та інвестиційною діяльністю. Розрахунок можливого варіанту руху грошових потоків в першу чергу спрямовано на покращення платоспроможності і фінансової стійкості підприємства за рахунок перерозподілу грошових коштів на користь основної діяльності. В наведеному умовному прикладі компанії «Альфа» навіть найоптимістичніший варіант використання грошових коштів не дозволить підприємству досягти оптимальних показників платоспроможності і фінансової стійкості. Це пояснюється тим, що за досліджуваний період компанія залучила значну суму довгострокових кредитів для потреб інноваційної діяльності. Внаслідок таких дій сума грошових коштів на погашення і обслуговування кредитних ресурсів (інвестиційна і фінансова діяльність) практично була рівна сумі, яка спрямовувалася на операційну діяльність. Такі дії власників компанії призвели до зменшення приросту грошових надходжень і прибутку від основної діяльності.

Стан грошових потоків, їх достатність та збалансованість можна оцінити за комплексом показників як за принципами експрес-аналізу, так i розширеного аналізу: динаміка номінальних значень позитивних i негативних грошових потоків, їх структури, величини структурних зрушень, місце у формування оборотного капіталу, співвідношення дебіторської заборгованості до зобов'язань, рівень ліквідності та ефективності грошового потоку, що доповнюють факторним аналізом та багатофакторних моделей тощо. Систематизація цих показників дає можливість повною мірою оцінити грошові потоки підприємства. Їх розрахунок та інтерпретація є результатом обліково-аналітичної роботи.

Висновки та перспективи подальших досліджень. Грошові потоки займають важливе місце у забезпеченні ліквідності та платоспроможності підприємства. Виконання завдань стратегічного управління неможливе без використання фактичних та прогнозних даних про рух грошових коштів підприємства. Це обумовлює гостру інформаційну необхідність у відповідному обліково-аналітичному забезпечення процесу управління. Його поліпшення залежить від ряду послідовних кроків, спрямованих на перегляд діючої системи управління підприємством та рівня організації обліково-звітної роботи. Вирішальну роль при цьому відіграють: повномасштабна автоматизація бухгалтерського обліку, побудова внутрішньогосподарського обліку та звітності про грошові потоки, їх інтеграція та інформаційно-аналітична взаємодія із іншими підсистемами управлінням, застосування сучасних систем аналізу та інтерпретації даних, розробки управлінських рішень та вибору оптимальних моделей руху грошових потоків.

\section{Список використаної літератури.}

1. Бойко Т.Ю. Механізм контролінгу грошових потоків суб'єкта господарювання: необхідність формування та реалізації // Науковий вісник Міжнародного гуманітарного університету. 2020. № 42. С. 166170. URL: http://www.vestnik-econom.mgu.od.ua/journal/2020/42-2020/31.pdf (дата звернення 11.12.2021).

2. Гриценко Л.Л., Боярко I.М., Роєнко В.В. Контролінг грошових потоків. Актуальні проблеми економіки. 2010. № 3. С. 148-154. URL: https://essuir.sumdu.edu.ua/bitstreamdownload/123456789/57169/5/Hrytsenko_Kontrolinh.pdf;jsessionid=BBAE47D6D79B809589AB75F60E5556C2 (дата звернення 15.01.2022).

3. Данилюк О.В. Формування обліково-аналітичної інформації для стратегічного управління грошовими потоками підприємства. Проблеми інтеграції облікових підсистем фінансового, податкового, управлінського і статистичного обліку в Україні відповідно до вимог Свропейських стандартів : зб. наук. пр. ЖНАЕУ. 2017. Т. ІІІ: Бухгалтерський облік в системі формування інноваційного інформаційного продукту для забезпечення функцій управління підприємством. http://ir.znau.edu.ua/bitstream/123456789/7634/1/PIOPF_2017_48-51.pdf (дата звернення 20.12.2017).

4. Колісник О. П., Замогильна А. В. Грошові потоки: сутність, класифікація та їх оптимізація в процесі управління. Modern Economics. 2018. № 10. С. 60-65. URL: https://modecon.mnau.edu.ua/issue/102018/kolisnyk.pdf (дата звернення 20.12.2021).

5. Кундря-Висоцька О.П. Інтеграція в обліку грошових потоків: передумови та необхідність. Тези Міжнародної наукової конференції «Розвиток обліку, аналізу і аудиту суб'єктів суспільного інтересу» (20-21 жовтня 2017 року). Житомир. 2017. С. 87-89.

6. Кучеренко Т. Проблеми класифікації грошових коштів у звіті про рух грошових коштів. Аграрна наука та освіта в умовах євроінтеграції: збірник наукових праць міжнар. наук.-практ. конф. Ч.2. (20-21 березня 2019 р., м. Кам’янець-Подільський). Тернопіль : Крок, 2019. С. 119-121.

7. Левченко Н.М., Скірко М.А. Обліково-аналітичне забезпечення стратегічного управління грошовими коштами як складовою монетарних активів підприємства. Сталий розвиток економіки. 2015 . № 1 . С. 213-219.

8. Мельник К.В. Аналіз грошових потоків підприємства як інструмент прийняття управлінських рішень у бізнесі. Корпоративні фінанси: проблеми та перспективи інноваційного розвитку: матеріали I Міжнар. наук.-практ. конф., 21 черв. 2017 р. / М-во освіти і науки України, ДВНЗ «Київ. нац. екон. ун-т ім. Вадима Гетьмана» [та ін.]; оргком.: В. К. Хлівний (голова) [та ін.]. Електрон. текст. дані. Київ : КНЕУ, 2017. С. $432-435$.

9. Міжнародний стандарт бухгалтерського обліку 7 «Звіт про рух грошових коштів»: Міжнародний документ у редакції від 01.01.2012 p. URL: https://zakon.rada.gov.ua/laws/show/929_019\#Tеxt (дата звернення: 23.12.2021). 
10. Поддєрьогін А. М. Фінанси підприємств : підручник / А. М. Поддєрьогін, М. Д. Білик. Л. Д. Буряк та ін. ; наук. ред. проф. А. М. Поддерьогін. 6-те вид., перероб. і доп. К. : КНЕУ, 2006. 552 с.

11. Про бухгалтерський облік та фінансову звітність в Україні: закон України від 16.07.1999 № 996XIV. URL: http://zakon.rada.gov.ua/cgi-bin/laws/main.cgi?nreg=996-14 (дата звернення: 15.12.2021).

\section{References.}

1. Bojko, T.Yu. (2020). "The mechanism of controlling the cash flows of the entity: the need for formation and implementation", Naukovyj visnyk Mizhnarodnoho humanitarnoho universytetu [Scientific Bulletin of the International Humanities University], [Online], Vol. 42. pp. 166-170, available at: http://www.vestnikeconom.mgu.od.ua/journal/2020/42-2020/31.pdf (Accessed December 11, 2021).

2. Hrytsenko, L.L., Boiarko, I.M., Roienko, V.V. (2010). "Controlling of the cash flows", Aktual'ni problemy ekonomiky [Current economic problems], Vol. 3. pp. 148-154, available at: https://essuir.sumdu.edu.ua/bitstreamdownload/123456789/57169/5/Hrytsenko_Kontrolinh.pdf;jsessionid=BBAE47D6D79B809589AB75F60E5556C2

(Accessed January 15, 2022).

3. Danyliuk, O.V. (2017). "Formation of accounting and analytical information for strategic management of cash flows of the enterprise". Collection of scientific works of Zhytomyr National Agroeconomic University, Vol. 3 (Accounting in the system of formation of innovative information product to ensure the functions of enterprise management), pp. 48-51, available at: http://ir.znau.edu.ua/bitstream/123456789/7634/1/PIOPF_2017_48-51.pdf (Accessed December 20, 2017).

4. Kolisnyk, O.P., Zamohyl'na, A.V. (2018), "Cash flows: essence, classification and their optimization in the management process", Modern Economics, vol. 10, pp. 60-65, available at: https://modecon.mnau.edu.ua/issue/102018/kolisnyk.pdf (Accessed December 20, 2021).

5. Kundria-Vysots'ka, O.P. (2017), "Integration in cash flow accounting: prerequisites and necessity", Tezy Mizhnarodnoi naukovoi konferentsii [Theses of the International Scientific Conference], Rozvytok obliku, analizu i audytu sub'iektiv suspil'noho interesu [Development of accounting, analysis and audit of public interest entities]», Zhytomyr, pp. 87-89.

6. Kucherenko, T. (2019), "Problems of classification of cash in the statement of cash flows", Ahrarna nauka ta osvita v umovakh ievrointehratsii [Agricultural science and education in the context of European integration], Zbirnyk naukovykh prats' mizhnar. nauk.-prakt. konf. [Collection of scientific works intern. scientific-practical conf.], Krok, Ternopil', Vol. 2, pp. 119-121.

7. Levchenko,, N.M., Skirko M.A. 92015), “Accounting and analytical support of strategic cash management as part of the monetary assets of the enterprise", Stalyj rozvytok ekonomiky [Sustainable economic development]. Vol. 1, pp. 213-219.

8. Mel'nyk, K.V. (2017), “Analysis of enterprise cash flows as a tool for making management decisions in business" Korporatyvni finansy: problemy ta perspektyvy innovatsijnoho rozvytku [Corporate finance: problems and prospects of innovative development], Materialy I Mizhnar. nauk.-prakt. konf. [Materials and International. scientificpractical conf.], KNEU, Kyiv, pp. 432-435.

9. The Verkhovna Rada of Ukraine (2012), International Accounting Standard 7 "Cash Flow Statement", available at: https://zakon.rada.gov.ua/laws/show/929_019\#Text (Accessed December 23, 2021).

10. Poddier'ohin A. M. (2006), Finansy pidpryiemstv [Enterprise finance], 6th ed, KNEU, Kyiv, Ukraine.

11. The Verkhovna Rada of Ukraine (1999), The Law of Ukraine "On the On accounting and financial reporting in Ukraine", available at: http://zakon.rada.gov.ua/cgi-bin/laws/main.cgi?nreg=996-14 (Accessed December 15, 2021). 